\title{
Emmanuella Robak
}

Uniwersytet Jana Kochanowskiego w Kielcach

\section{Ludzkość w perspektywie mitów. Uwagi na marginesie Trylogii księżycowej Jerzego Żuławskiego}

Mit to cząstka ludzkiej rzeczywistości - prastara, obrosła w stereotypy, a zarazem wiecznie żywa, ciągle aktualna, do dziś ciesząca się tak dużym zainteresowaniem rozmaitych badaczy, że trudno precyzyjnie zdefiniować, czym właściwie jest. Na samym wstępie warto więc zapytać, czy

mit wciąż postrzegany jest jako narracja o świecie otaczającym człowieka, opowieść, w której główną rolę odgrywają bogowie, bóstwa, siły nadprzyrodzone lub herosi, czy też raczej myśli się o nim przede wszystkim w kategoriach trwania oraz oddziaływania w różnych epokach historycznych i przejawiania się w rozmaitych kontekstach kulturowych? ${ }^{1}$

Na pewno jest to „wcześniej lub później weryfikowalny lub falsyfikowany obraz świata rzeczywistego"2, odnoszący się do sfery emocjonalnej człowieka oraz takiej symboliki, która jest dla niego zrozumiała. Jest to również próba tłumaczenia niemal wszystkich uniwersalnych zagadnień bytu, problemu dobra i zła, odwiecznych tajemnic, na które nie ma (i prawdopodobnie nigdy nie będzie) jednoznacznej odpowiedzi.

Krytycy zajmujący się mitami wyodrębniają trzy zasadnicze sposoby definiowania tego zjawiska. W pierwszej kolejności można tłumaczyć mity w znaczeniu węższym, które sprowadza się do następującej teorii:

${ }^{1}$ P. J. Fereński, Słowo o micie. Mit w kontekście antropologii wiedzy, [w:] Mit poczatku, mit drogi, red. B. Płonka-Syroka, E. Rudolf, Wrocław 2010, s. 25.

${ }^{2}$ S. Hrebenda, Mitologia społeczna $w$ literaturze fantastycznonaukowej, Katowice 2000, s. 19. 
mity skupiają się na motywach dotyczących stworzenia świata, stworzenia człowieka, jego istnienia i zbawienia, są to opowieści o życiu bogów, życiu po śmierci, życiu doczesnym (...). Mit jest w tym rozumieniu opowieścią świętą dla tych, którzy w niego wierzą, uzasadnia realny porządek społeczny oraz zasady moralne ${ }^{3}$.

Drugie, szersze znaczenie mitów określa je jako charakterystyczny dla społeczeństw, pierwotnych bądź tradycyjnych, archaiczny światopogląd, który formułuje sposób odczuwania świata ${ }^{4}$. Trzecie odczytanie mitów przedstawia je jako sposób myślenia, coś uniwersalnego, właściwego wszystkim zbiorowościom, społeczeństwom i każdemu typowi kultury ${ }^{5}$.

Myślenie mityczne wydaje się przeciwstawne poznaniu racjonalnemu, kontrastujące $\mathrm{z}$ prawdami naukowymi. Okazuje się jednak, że rozdzielenie mitu i nauki nie jest możliwe w sposób radykalny. Mit może inspirować naukę do badań rzeczywistości, a mitotwórstwo bardzo często związane jest z „naukowym bądź sakralnym wyjaśnieniem świata" ${ }^{6}$. Interesujący pomost pomiędzy mitami a nauką buduje fantastyka naukowa7 , która jako gatunek literacki (ale nie tylko) tworzy przestrzeń do podejmowania dyskusji z pojęciami mitycznymi czy też inspiruje do głębszego namysłu nad miejscem człowieka we wszechświecie. Przestrzenie fantastyczne, które zazwyczaj opisują utopijne wizje świata, doskonale sprawdzają się jako płaszczyzna dialogu między mitami a rzeczywistością. W fantastyce wiele zagadnień można poddać gruntownemu badaniu naukowemu, przewartościowaniu czy dekonstrukcji, bowiem pomysły autorów dzieł z nurtu science fiction są bardzo często częścią eksperymentu myślowego. Powszechnym zabiegiem

${ }^{3}$ E. Nowicka, Świat człowieka - świat kultury, Warszawa 1991, s. 429.

${ }^{4}$ R. Tomicki, Mit, [w:] Stownik etnologiczny, red. Z. Staszczak, Warszawa-Poznań 1987, s. 244.

${ }^{5}$ Ibidem.

${ }^{6}$ S. Hrebenda, op. cit., s. 125.

7 Zob. ibidem, s. 66-76. 
autorów opisujących przestrzenie alternatywne jest obalanie starych mitów i - na ich ruinach - tworzenie zupełnie nowych.

Wprowadzanie wątków mitycznych w ramy science fiction jest współcześnie bardzo popularne, a zwyczaj ten sięga - w wypadku literatury polskiej - drugiej połowy XIX wieku. Szczególnie zauważalny jest w prozie młodopolskiego twórcy, należącego do prekursorów rodzimej literatury fantastycznej, Jerzego Żuławskiego. W swojej powieści opisującej losy nowej cywilizacji zapoczątkowanej przez człowieka ustosunkował się on do wielu mitów, kreując ich nową wersję literacką, która jest:

prawie zawsze mitem zdesakralizowanym, pozbawionym sankcji religijnej i dostępu do transcendencji. Jest cieniem swego religijnego prawzoru, dalekim refleksem prawdziwej historii stworzenia świata ${ }^{8}$.

Żuławski, pisząc swoje trzytomowe dzieło o nowej cywilizacji, zamierzał zaprezentować czytelnikom własne stanowisko wobec różnych kwestii: społecznych, filozoficznych oraz religijnych. Twórca należał do pokolenia modernistów, generacji ludzi, których charakteryzowała wielość zainteresowań i których pisarstwo determinowały tendencje oraz mody epoki: dekadentyzm, mediumizm, monizm, nauki indyjskie, buddyzm, filozofia Wschodu i inne. Nic więc dziwnego, że powieść, będąca przedmiotem analizy i interpretacji w niniejszym rozdziale, odzwierciedla filozoficzno-refleksyjne pasje młodopolskiego autora i porusza wiele kwestii charakterystycznych dla jego światopoglądu. Przedstawienie osobistych refleksji za pośrednictwem futurologicznych wizji oraz dzięki twórczej reinterpretacji znanych mitów stworzyło pisarzowi sposobność ,swobodnej parafrazy mitu w antymit, w stereotyp, w symbol", a także umożliwiło wyrażenie obaw i przekonań na temat kondycji ludzkości.

${ }^{8}$ Beatrycze $i$ inne. Mity kobiet $w$ literaturze i kulturze, red. G. Borkowska, L. Wiśniewska, Gdańsk 2010, s. 6.

9 Ibidem, s. 6. 
Trylogia księżycowa Żuławskiego (skomponowana z trzech części: Na srebrnym globie, Zwycięzca i Stara ziemia) jako całość jest tekstem uwikłanym w rozmaite mity - jak soczewka skupia je i rozprasza zarazem. Autor sięgnął po uniwersalne mity ludzkości, takie jak: mit Raju i „Ziemi Utraconej”, mit genezyjski (narodziny nowej cywilizacji pozaziemskiej), antropogeniczny (związany z płciowością, śmiertelnością, kulturą), mit pierwszej kobiety (Rodzicielki rodzaju ludzkiego, biblijnej Ewy) i femme fatale (modernistycznej modliszki), mit „Świętej Księgi” (Boga-Zbawcy) i Anty-Mesjasza. Jak pisze Dariusz Trześniowski, w powieści autora Erosa i Psyche:

ziemia urasta do roli Raju Utraconego, cała wyprawa nazywana jest exodusem, druga strona Księżyca, gdzie możliwe jest życie, jest Ziemią Obiecaną. Marta i Tomasz są prarodzicami nowego ludu księżycowego ${ }^{10}$.

Żuławski był przekonany, że ludzką wyobránią władają prawa religijne, które systematyzują świat „w wymiarach transcendentalnego sensu”" ${ }^{\prime 1}$. Mit w takim rozumieniu „odwołuje się więc nie tyle do wiedzy, ile do wiary"12, którą łatwo wytłumaczyć, zaakceptować lub jeszcze prościej zanegować.

Powieściowy tryptyk rozpoczyna się od opisu podróży bohaterów, grupy śmiałków, którzy „gotowi zresztą byli na śmierć, byle wydrzeć przedtem gwiaździstemu niebu bodaj jedną z tych jego tajemnic, które tak zazdrośnie ukrywa przed człowiekiem”"13. Piątka ochotników - czterech mężczyzn i jedna kobieta (dołączyła do podróżników przypadkowo, zastępując jednego z mężczyzn, który w ostatniej chwili wycofał się z eskapady) - zapragnęła

${ }^{10}$ D. Trześniowski, Młodopolskie źródła fantasy. „Trylogia księżycowa” Jerzego Żuławskiego, [w:] Modernistyczne źródła dwudziestowieczności, red. A.Z. Makowiecki, M. Dąbrowski, Warszawa 2003, s. 202.

11 Ibidem, s. 202.

12 S. Hrebenda, op. cit., s. 22.

13 J. Żuławski, Na srebrnym globie, Kraków 1975, s. 26. 
zrealizować odwieczne marzenia człowieka „o założeniu tam, na tej jasnej ziemi, w ciche noce świecącej kuli, nowego społeczeństwa, nowej ludzkości, szczęśliwszej... może”14. Można pokusić się o stwierdzenie, że stworzenie nowej rzeczywistości, napisanie pierwszego rozdziału nowej księgi Genesis i próba reaktualizacji mitu genezyjskiego stały się zasadniczym celem Jana, Tomasza, Piotra, O’Tamora oraz Marty, choć ta ostatnia nawet nie przypuszczała, że to jej przypadnie odegrać znaczącą rolę w narodzinach księżycowej rzeczywistości. Jako pierwsza kobieta, pramatka nowego pokolenia staje się odpowiedniczką biblijnej Ewy. Synowi Marty - Tomowi - autor powierza równie doniosłą funkcję: ma zapoczątkować nową erę i nowy świat. Marta zatem jako matka nowej cywilizacji wpisuje się w mit pierwszej kobiety, rodzicielki rodzaju ludzkiego (w tym przypadku rodzaju księżycowego), a jej syn - w mit biblijnego Adama.

O samej wyprawie na Księżyc ,pisano - jak mowa jest w narracji poprzedzającej Dziennik podróży - już tylko jako o szaleństwie, będącym wprost zbrodnią"15, rodzajem gwałtu na podstawowych prawach natury. Ale ten gwałt na naturze dokonany był w imię wyższych celów. Ludzkość od wieków próbowała odszukać swoje właściwe miejsce we wszechświecie, odnaleźć swój raj. Ten miał przypominać Eden - Raj stworzony przez Boga dla pierwszych ludzi - Adama i Ewy, który był miejscem, gdzie wszystko było dozwolone, wszystkiego było pod dostatkiem i ze wszystkiego można było korzystać, z jednym wyjątkiem - pierwszym rodzicom nie wolno było spożywać owoców z drzewa poznania dobra i zła. Jednak ludzka ciekawość i niedoskonałość doprowadziły do błędu, za który pokutować miały wszystkie kolejne pokolenie. Odkąd pierwsi ludzie złamali zakaz zrywania owocu z zakazanego drzewa, ludzkość została zmuszona do życia na ziemi, na której troska, ból, cierpienie, zwątpienie i choroby stanowić miały nierozerwalną

\footnotetext{
14 Ibidem.

15 Ibidem, s. 19.
} 
część egzystencji. Odtąd też człowiek skazany został na błąkanie się po ziemi, a jego zagubiona dusza na niezaspokojoną tęsknotę do innego świata - tego lepszego, świadomie utraconego. Bohaterowie Na srebrnym globie Żuławskiego chcą ten stan zmienić, dlatego wyruszają na Księżyc, by choć trochę przybliżyć się do tej lepszej (rajskiej) rzeczywistości.

Pragnienie doświadczenia alternatywnej egzystencji jest silniejsze niż odruch pozostania w świecie dobrze już znanym. Poznanie sfery nieznanej, niezbadanej i dzikiej stanowi nieodpartą pokusę, niczym jabłko z drzewa dobra i zła. Bohaterowie chcą odkryć nowe krainy, rozpocząć nowe życie, spotkać być może nawet innych ludzi, mimo iż są świadomi (a może właśnie dlatego), że na ziemię nigdy nie wrócą, bo nie mają takiej technicznej możliwości. Ich wyprawa jest wycieczką w jedną stronę, postawieniem wszystkiego na jedną kartę, ale wierzą, że śmiertelne ryzyko może być opłacalne.

Planeta księżycowa od samego początku okazuje się jednak niegościnna - nie chce na swoich terenach obcych. Bohaterom towarzyszą rozczarowanie, zawód i śmierć. Z tęsknotą patrzą na spoglądającą na nich z niebotycznie oddalonego nieba Ziemię, która

zamieniła się w oko rozwarte, bezlitosne i czujne i wpatruje się uporczywie a ze zdziwieniem w nas, którzyśmy od niej uciekli ciałem - pierwsi ze wszystkich jej dzieci ${ }^{16}$.

Kompletne rozczarowanie, nicość, nihilizm, troska, trwoga i śmierć - to zasadnicze uczucia, które towarzyszą grupie podróżników. Marazm i powtarzalność codziennych czynności potrafią wyprowadzić z równowagi niemal każdego uczestnika wyprawy. Wszyscy już wiedzą, że:

potem przyjdzie znów noc. Po nocy znów dzień, taki sam, jak poprzedni i znowu noc i znów dzień - i tak bez końca, bez odmiany, bez pór roku, bez lat, bez miesięcy... Jeśli dożyjemy... ${ }^{17}$.

${ }^{16}$ Ibidem, s. 34.

${ }^{17}$ Ibidem, s. 31. 
Jan Korecki, główny bohater powieści, który nigdy nie zapomniał o Ziemi i zawsze pragnął na nią powrócić, w finale pierwszej części trylogii skomentuje życie na Księżycu w taki oto sposób:

\begin{abstract}
wszystkie nieszczęścia, wszystkie złe namiętności i nędze ludzkie, które tam od wieków prześladują ród człowieczy, nie wyłączając i groźnej ich królowej - nieubłaganej śmierci, przyszły tu za nami, na ten glob dotąd cichy i spokojny w swej martwocie. Wszędzie źle jest człowiekowi, bo wszędzie nosi sam w sobie zaród nieszczęścia ${ }^{18}$.
\end{abstract}

Refleksję Jana, ostatniego ziemskiego potomka, metaforycznie puentuje scena jego śmierci - w momencie odejścia spogląda w stronę Ziemi, którą widać z Księżyca, i zachowując w pamięci ten widok, opuszcza na zawsze księżycową przestrzeń.

Mit genezyjski niespodziewanie przerodził się w tryptyku powieściowym Żuławskiego w apokaliptyczną rzeczywistość. Na przekór niej wiara $\mathrm{w}$ to, że nowe stworzenie, mające nastąpić po starym, będzie jeszcze piękniejsze niż pierwotne i że w końcu wszystkie cierpienia ludzkie okażą się ułudą, błahostką i marnością, jest tak silna, że chwilowe przeciwności losu traktowane są przez odkrywców księżycowej krainy wyłącznie jak stan przejściowy. Pomimo że bohaterowie pierwszej części Trylogii księżycowej nie odnaleźli w lunarnej przestrzeni poszukiwanego raju, nadzieja na jego istnienie pozostaje w pokoleniu, które stworzyli. Nowa cywilizacja, zrodzona z ziemskich ludzi - Marty i Tomasza - ma być w założeniu szczęśliwszym, doskonalszym wymiarem pozaziemskiej egzystencji. Jest to wszakże jedynie modelowa (utopijna) cywilizacja, której twórcy marzą o zaznaniu rajskiego życia.

Po śmierci ziemskich ludzi nowe pokolenie rodzi się ze związków kazirodczych - są to więc ludzie ułomni, skarłowaciali, nienaturalni, brzydcy i głupi. Ich działaniami kierują biologia, instynkty seksualne i brutalna walka o byt, nieodparta chęć zemsty, władzy i zabijania. Czynniki antropogeniczne (związane z płciowością,

${ }^{18}$ Ibidem, s. 216. 
kulturą, śmiertelnością) aktywują całą strukturę zachowań, które wpisane są w pierwotną naturę człowieka. Selenici tworzą własną kulturę, nacechowaną przede wszystkim cielesnością, zmysłowością i zaspokajaniem popędów, a jedynym celem ich istnienia jest walka o przetrwanie - nie tylko danego rodu, który obecnie żyje na księżycowej ziemi, ale także o przetrwanie księżycowych pokoleń.

Ta pozornie szczęśliwa cywilizacja odkrywa w końcu mroczne strony ziemskiej natury człowieka (pamiętać należy, że to pokolenie ma wszak korzenie ludzkie). Egoizm, despotyzm, barbarzyństwo i prymitywizm to charakterystyczne wyznaczniki egzystencji na srebrnym globie. Zachowanie selenitów może mieć jednak jeszcze inne podłoże. Lunarną, prymitywną kulturę łączą mity, które ewoluują, ciągle się rozbudowują i ulegają nieustannym przeobrażeniom. Na planecie księżycowej żyją zarówno selenici, morce, jak i szernowie (ci ostatni to cywilizacja księżycowa, która istniała tam jeszcze przed przybyciem ziemskich ludzi). Nie ma możliwości, z antropologicznego i socjologicznego punktu widzenia, by ich wzajemne wierzenia mityczne się nie przenikały:

żadna $\mathrm{z}$ tych ewolucji nie mogła nie wyjść na zewnątrz, nie powodując jednocześnie transformacji analogicznych bądź opozycyjnych, będących efektem reakcji tak często obserwowanych między bliskim sąsiadami ${ }^{19}$.

Bestialskość, brak empatii, chęć zemsty szernów wpływa na zachowanie selenitów, którzy zaczynają wierzyć, że tak należy się zachowywać. Selenici jednak kompletnie nie zdają sobie sprawy $\mathrm{z}$ tego, że popełniają dokładnie te same błędy, które popełniali ludzie na Ziemi - krzywdzą siebie nawzajem, walczą ze sobą, chcą unicestwić wrogów, by zdobyć władzę. Na Księżycu pokolenie lunarne tworzy nie tylko kontrowersyjny system wartości, ale także religię, która odgrywa w jego życiu ogromną rolę. Traktuje Jana, ostatniego z żyjących ludzi, jak Boga. Wierzy także, że bohater po

${ }^{19}$ C. Lévi-Strauss, Drogi masek, przeł. M. Dobrowolska, Łódź 1985, s. 145. 
swej śmierci pewnego dnia zmartwychwstanie i powróci do nich, by uratować lud księżycowy przed zgubą. Nazywany przez ludzi księżycowych Starym Człowiekiem, Jan nie do końca jednak wpisuje się w rolę „człowieka charyzmatycznego” dla nowego pokolenia. Buntuje się przeciwko temu, że jest przez jego członków uważany za wyrocznię, ale też nie robi nic, co mogłoby wpłynąć na ich świadomość i zmienić ich sposób myślenia. Oddala się stopniowo od księżycowych ludzi między innymi dlatego, że ich widok budzi w nim odrazę. W myślach Jana Koreckiego rodzi się pełna tragizmu refleksja, że powołanie do życia nowej cywilizacji na Księżycu było zbrodnią, która będzie się mścić przez następne wieki. Jan jest wobec księżycowych ludzi niesprawiedliwy, widząc w nich pomyłkę natury i karę za własne grzechy (opuszczenie Ziemi). Oni sami nie są przecież niczemu winni - kierują się niepohamowanym instynktem, którego nie są w stanie okiełznać, bo nikt ich nie nauczył zasad etycznego zachowania.

Gdy Jan umiera, pokolenie księżycowe korzysta z jego zapisków, które zostawił potomności, uznając je za mityczną „Świętą Księgę”, dającą im nadzieję na przyjście wyczekiwanego Boga-Zbawcy. Jan, sporządzając prywatne zapiski, był przekonany, że jest to praca zupełnie bezcelowa, sądził, że pokolenie selenitów zupełnie nie zrozumie jego nauk. W praktyce okazuje się, że następne pokolenia selenitów będą żyć i postępować według zamieszczonych w księdze wskazówek. „Święta Księga” Jana będzie odpowiadać na wszystkie pytania, stanowiące trudne do rozstrzygnięcia kwestie; będzie „decydować” o sprawiedliwości i wyrokach wydawanych na zdrajcach itp. Selenici oczywiście odczytywali zapiski Starego Człowieka według własnej (często błędnej) interpretacji, nie mieli bowiem nigdy mądrego nauczyciela, który wytłumaczyłby im mechanizm podejmowania decyzji, wyborów, tworzenia systemów wartości i moralności itp.

Zainteresowanie selenitów religią stanowi fakt socjologiczny, który badał Emil Durkheim, wnioskując, że: 
wszystkie instytucje społeczne pochodzą z religii, życie religijne jest wyrazem całości życia społecznego. Sama idea społeczeństwa jest duszą religii. Natomiast wszystkie moralne normy z niej wypływające są wytworami świadomości zbiorowej ${ }^{20}$.

Niestety bez odpowiednich, ugruntowanych podstaw aksjologii i etyki cywilizacja przeniesiona na Księżyc zamiera. Selenitami, pozbawionymi stabilnego kodeksu wartości, można w łatwy sposób manipulować, ponieważ

odwołując się do mitów, które wyjaśniają, usprawiedliwiają, a czasem uświetniają panujące warunki życia, manipulatorzy zapewniają powszechne poparcie dla porządku społecznego, który na dłuższą metę nie służy prawdziwym interesom większości. Kiedy manipulacja jest skutkiem, ludzie nie myślą o alternatywnych rozwiązaniach ${ }^{21}$.

Manipulację jednak zawsze można zdemaskować i próbować naprawić szkody, które powstały w jej wyniku. Taka próba zostaje podjęta w części drugiej tryptyku Żuławskiego.

Drugi tom trylogii, zatytułowany Zwycięzca, prezentuje dalsze losy księżycowego pokolenia, w życiu którego dominują już niemal wyłącznie instynktowne zachowania i chęć przetrwania za wszelką cenę. Księżycowi ludzie mają jednak pewien nadrzędny cel - oczekują na przyjście mesjasza, który zmieni całe ich życie. W końcu wyczekiwany mesjasz, zwycięzca, nadchodzi - na Księżyc przylatuje Marek, turysta i ciekawski eksplorator nieznanych przestrzeni. Od poprzedniej wizyty ludzi na Księżycu minęło już 700 lat. Przez ten czas pokolenie selenitów zdążyło podzielić się na dobrych i złych, przeprowadzić kilkadziesiąt wojen o terytoria i władzę, a także zbudować niezwykły system zasad, który w oczach Ziemianina jest potwornością.

${ }^{20}$ S. Rogala, Społeczne i filozoficzne poglady Jerzego Żuławskiego, [w:] Jerzy Żuławski. Życie i twórczość. Referaty i materiały z sesji naukowej, red. E. Łoch, Rzeszów 1976, s. 162.

${ }^{21}$ H.I. Schiller, Sternicy świadomości, przeł. U. Szczepańczyk, Kraków 1976, s. 13 . 
Marek od razu urasta w oczach selenitów do rangi Zbawcy, kreatora nowego porządku, który przybył na Księżyc, by dokonać zmian, wprowadzić nowe przepisy, bo stare nie odpowiadają już wymogom czasu. Selenitów fascynuje ogromna moc Marka (przywiózł ze sobą broń palną i w ciągu jednej sekundy rozprawił się z mieszkańcem wrogiego obozu); wierzą, że jego poczynania mogą przynieść pożądany skutek. Marek początkowo dystansuje się od powierzonej mu roli, jednak z czasem zaczyna wykonywać dokładnie to, czego oczekują od niego selenici. Wśród księżycowej społeczności tylko Malahuda, wyznawca religii Starego Człowieka, nie ufa Markowi. Od samego początku przeczuwa, że mit człowieka-zbawcy jest tylko ułudą. Kiedy dotarła do niego wieść o Mesjaszu-Zbawcy:

za każdą cenę nie chciał - tak jest, nie chciał - wierzyć temu, co się stało. Teraz już idąc przez puste krużganki z przybyłymi z wieścią posłami, nie taił nawet przed sobą, że wprost pragnie, aby wieść okazała się fałszywa $^{22}$.

Jego rozczarowanie było ogromne, bowiem „zamiast radości posępność coraz większa a niewytłumaczona spadała mu na duszę"23. Marek nie dawał wiary słowom Malahudy, który uprzedzał go, że jedyną drogą do zawładnięcia cywilizacją księżycową jest despotyzm. „Zwycięzca” chciał wprowadzić własne rządy. Uznał siebie za kogoś, kto może pretendować do roli władcy, ponieważ jako jedyny wśród księżycowych ludzi pochodził z innej planety. Niestety bardzo szybko stracił zwolenników. Niechęć wobec przybysza z czasem się nasilała, głównie z tego powodu, że „wziął się samowolnie do zmieniania odwiecznych i uświęconych praw, określających porządek życia na Księżycu"24.

W finale Zwycięzcy Marek ginie z rąk selenitów. Traci życie zgodnie $\mathrm{z}$ formułą losu mesjasza, który wchodząc $\mathrm{w}$ daną

\footnotetext{
22 J. Żuławski, Zwycięzca, Kraków 1979, s. 21.

${ }^{23}$ Ibidem, s. 22.

${ }^{24}$ Ibidem, s. 311.
} 
społeczność, zazwyczaj skazany jest na śmierć. Analogia do ewangelicznych wydarzeń nie jest tu przypadkowa, bowiem ,powtarzanie się legendy jest wyrazem powstawania «symbolu jednoczącego» społeczeństwa i zbiorowości”25. Śmiertelny cios wymierza Markowi ukochana kobieta - Ihezal (wnuczka Malahudy, która mści się za śmierć swojego dziadka). Na prawach kontrastu kobiecie pramatce z pierwszej części trylogii Żuławski przeciwstawia w jej drugiej części femme fatale, kobietę modliszkę, której aktywność sprowadza się do zguby partnera, wykorzystania, świadomego niszczenia. Taka jest właśnie Ihezal, żądna krwi i zemsty, pozbawiona skrupułów i empatii ${ }^{26}$.

Uwikłanie powieści Żuławskiego w mity potwierdza znany mechanizm: człowiek jest istotą mitotwórczą, która potrzebuje spójnego i sensownego obrazu świata:

mit bowiem zaspokaja potrzeby, niemożliwe do zaspokojenia w inny sposób, jest rodzajem zbioru skojarzeń, którymi się myśli i uzasadnia to, co nieuzasadnione i zapewne nieuzasadnialne na drodze empirycznej ${ }^{27}$.

Nawiązując do refleksji Claude’a Lévi-Straussa, warto podkreślić też inną kwestię. Badacz ten zauważa:

niektórzy twierdzą, że każde społeczeństwo wyraża w swoich mitach podstawowe uczucia, takie jak: miłość, nienawiść, mściwość, które są wspólne całej ludzkości (...) właściwym przedmiotem mitów jest dostarczanie ujścia uczuciom rzeczywistym, ale tłumionym ${ }^{28}$.

Faktycznie, jeśli spojrzymy na cywilizację księżycową wykreowaną przez Żuławskiego, dopatrzymy się w niej przede wszystkim

${ }^{25}$ S. Hrebenda, op. cit., s. 22.

${ }^{26}$ Zob. D. Trześniowski, „Femme fatale” w tekstach Jerzego Żuławskiego, [w:] Zasługi Jerzego Żuławskiego i jego rodu dla literatury i kultury polskiej XX wieku, red. E. Łoch, D. Trześniowski, Lublin 2011, s. 29-46.

27 E. Nowicka, op. cit., s. 426.

${ }^{28}$ C. Lévi-Strauss, Antropologia strukturalna, przeł. K. Pomian, Warszawa 1970, s. 286. 
rysów zbiorowości, która nie tłumi swoich pierwotnych odruchów i emocji (takich jak: instynkt walki, działania bezwarunkowe, potrzeba wiary i religii), przez co tworzenie mitów i funkcjonowanie według nich staje się zachowaniem jak najbardziej naturalnym. Autor Trylogii księżycowej zaprezentował odbiorcy oryginalną wizję pokolenia księżycowego po to, by w jego prywatnym, „literackim lustrze” przejrzały się odwieczne, stare mity ludzkości.

\section{Bibliografia}

Beatrycze i inne. Mity kobiet $w$ literaturze i kulturze, red. G. Borkowska, L. Wiśniewska, Gdańsk 2010.

Fereński P. J., Słowo o micie. Mit w kontekście antropologii wiedzy, [w:] Mit począt$k u$, mit drogi, red. B. Płonka-Syroka, E. Rudolf, Wrocław 2010.

Hrebenda Sz., Mitologia społeczna w literaturze fantastycznonaukowej, Katowice 2000.

Nowicka E., Świat człowieka - świat kultury, Warszawa 1991.

Lévi-Strauss C., Drogi masek, przeł. M. Dobrowolska, Łódź 1985.

Lévi-Strauss C., Antropologia strukturalna, przeł. K. Pomian, Warszawa 1970.

Tomicki R., Mit, [w:] Stownik etnologiczny, red. Z. Staszczak, Warszawa-Poznań 1987.

Trześniowski D., Młodopolskie źródła fantasy. „Trylogia księżycowa” Jerzego Żuławskiego, [w:] Modernistyczne źródła dwudziestowieczności, red. A.Z. Makowiecki, M. Dąbrowski, Warszawa 2003.

Trześniowski D., „Femme fatale” w tekstach Jerzego Żuławskiego, [w:] Zastugi Jerzego Żuławskiego i jego rodu dla literatury i kultury polskiej XX wieku, red. E. Łoch, D. Trześniowski, Lublin 2011.

Rogala S., Społeczne i filozoficzne poglady Jerzego Żuławskiego, [w:] Jerzy Żuławski. Życie i twórczość. Referaty i materiały sesji naukowej, red. E. Łoch, Rzeszów 1976.

Schiller H. I., Sternicy świadomości, przeł. U. Szczepańczyk, Kraków 1976.

Żuławski J., Na srebrnym globie, Kraków 1975.

Żuławski J., Zwycięzca, Kraków 1979. 